\title{
Delayed Progression to Dialysis with Early and Intensive Management of Predialysis Chronic Kidney Disease: A Case-Based Approach
}

\author{
Stephen Thomsen \\ Hudson Essex Nephrology, Union City, N.J., USA
}

\section{Key Words}

Chronic kidney disease · Estimated GFR · Comorbidities · Multifactorial treatment regimen

\begin{abstract}
In addition to hypertension and diabetes, disorders in mineral metabolism and bone disease (e.g. affecting phosphorus, calcium, parathyroid hormone, and vitamin D) are common complications of chronic kidney disease (CKD) and contribute to morbidity and mortality. Consequently, CKD requires multifactorial treatment to slow CKD progression and avoid endstage renal disease. CKD progression and treatment outcomes are monitored by measuring the estimated glomerular filtration rate (eGFR), which decreases by $2-12 \mathrm{ml} / \mathrm{min} / 1.73 \mathrm{~m}^{2}$ per year depending on the stage of CKD and comorbidities, such as diabetes. This paper presents representative case studies illustrating the delay and reversal of CKD progression with comprehensive, individualized treatment regimens, including non-calcium phosphate binders, antihypertensives, lipid-lowering drugs, calcimimetics, and other drugs as required, to treat each component of CKD including CKD-mineral and bone disorder. Four patients are included, with an average age of 70-81 years and CKD stage 3 or 4 accompanied by various comorbidities, most notably diabetes and hypertension. The range of treatment and followup durations was 6-7 years. In each case, there was evidence of slowing or prevention of CKD progression, according to eGFR and serum creatinine, regardless of the patient's age or CKD stage. Despite a baseline eGFR of $<20 \mathrm{ml} / \mathrm{min} / 1.73 \mathrm{~m}^{2}$ in 1 female patient, after 6 years of follow-up, her eGFR had stabilized and was maintained at $>15 \mathrm{ml} / \mathrm{min} / 1.73 \mathrm{~m}^{2}$. These observations reinforce the value of early nephrology referral and comprehensive management of CKD and underlying conditions (hypertension and diabetes) beginning at eGFR $<60$ $\mathrm{ml} / \mathrm{min} / 1.73 \mathrm{~m}^{2}$.
\end{abstract}




\section{Introduction}

Chronic kidney disease (CKD) is an increasingly prevalent healthcare burden, affecting approximately $13 \%$ of the US population [1]. Hypertension and type 2 diabetes are the major causes of CKD and are important treatment targets. In addition, CKD is often accompanied by metabolic disturbances including hyperphosphatemia, vitamin D deficiency, and metabolic acidosis, which are therefore also important therapeutic targets. As a consequence, a multifactorial treatment approach is advocated to treat the causes and consequences of CKD, to slow CKD progression, and to avoid end-stage renal disease (ESRD) [2]. Early referral to a nephrologist is also essential to slow progression of CKD and avoid complications of ESRD $[3,4]$.

CKD is defined as a progressive loss of kidney function where the glomerular filtration rate (GFR) is $<60 \mathrm{ml} / \mathrm{min} / 1.73 \mathrm{~m}^{2}$ or there is evidence of kidney damage for at least 3 months [5]; evidence of kidney damage may include abnormal proteinuria or microscopic hematuria, with additional abnormalities related to anatomy, radiology, or histopathology. Estimated GFR (eGFR) is the preferred method over change in albuminuria to assess kidney function, since changes in GFR are more consistent with progressive deterioration in renal function [6,7]. The relationship between change in proteinuria and worsening GFR also suggests that reduced albumin excretion may not be a meaningful clinical outcome [2].

Reliable and accurate estimations of GFR using the Modification of Diet in Renal Disease (MDRD) equation [8] and, more recently, the Chronic Kidney Disease Epidemiology Collaboration equation [9] have been reported. Studies indicate that there can be a 2-12 $\mathrm{ml} / \mathrm{min} / 1.73 \mathrm{~m}^{2}$ annual loss in eGFR on average with renal disease [10] and an annual decline in eGFR of $1-8 \mathrm{ml} / \mathrm{min} / 1.73 \mathrm{~m}^{2}$ in diabetic patients with micro/macroalbuminuria [11]. More recent studies indicate that eGFR declines by an average of $5.8 \mathrm{ml} / \mathrm{min} / 1.73 \mathrm{~m}^{2}$ per year in patients with type 2 diabetes and preserved kidney function [12], while patients with diabetes and advanced renal disease who received an angiotensin receptor blocker (ARB) showed a similar decline of approximately $5 \mathrm{ml} / \mathrm{min} / 1.73 \mathrm{~m}^{2}$ per year $[13,14]$. The benefit of antihypertensive therapy on eGFR decline is exemplified by Murussi et al. [15] who demonstrated that patients with diabetes not receiving early antihypertensive treatment experienced an annual decline of $10-14 \mathrm{ml} / \mathrm{min} / 1.73 \mathrm{~m}^{2}$. Early studies comparing reciprocal serum creatinine semilogarithmic curves showed that different disease entities and specific diagnoses had different slopes: diabetic renal disease was associated with very steep curves and led to a rapid decline in GFR and dialysis dependence. As GFR declined, it was also apparent that a more rapid decline and steeper slope of the curve was associated with ESRD [10]. These concepts are useful to compare and contrast with the results presented in this case series.

\section{Cardiovascular Disease Risk and Mineral Metabolism in CKD}

Patients with CKD are exposed to competing risks: progression of CKD to ESRD and increased cardiovascular disease (CVD) risk (compared to patients without CKD). The relative risk of CVD-related mortality is 6 times higher than the risk of progressing to ESRD [16]. CKD is also a greater risk factor than diabetes for future coronary events in high-risk patients [17]. CKD tends to aggravate traditional CVD risk factors, such as hyperlipidemia, which should be assiduously managed in renal-impaired patients [2]. Additional CKDspecific sources of CVD risk include uremic toxins, advanced glycation endproducts (AGEs), 
and the mineral and endocrine derangements of CKD-mineral and bone disorder (CKD-MBD) [2].

CKD-MBD comprises metabolic abnormalities affecting phosphorus, calcium, parathyroid hormone (PTH), vitamin D, bones (e.g. affecting bone turnover, strength, and volume), and calcification of vascular or other soft tissue [18]. Not only is hyperphosphatemia itself a source of cardiovascular pathology, but the preceding elevations in PTH and fibroblast growth factor (FGF)-23 also contribute to cardiovascular and renal risk; FGF-23 elevation is associated with CKD progression [2] and causes left ventricular hypertrophy [19]. Studies on human CKD suggest that sevelamer [20] or lanthanum binders [21] lower serum FGF-23, while the use of calcium binders does not [20,21]. Uremic animal models suggest that a positive calcium balance (from a diet, supplements, and calcium-based phosphate binders) can fuel vascular and valvular calcification in CKD/ESRD [22, 23]. In human CKD patients, a positive calcium balance may contribute to the deposition of calcium in soft tissue [24]. An excess of calcium has been associated with an increased CVD risk in the general population [25].

The current Kidney Disease Improving Global Outcomes (KDIGO) guidelines for CKDMBD recommend evaluating serum phosphorus, calcium, and PTH every 6-12 months, if eGFR is $30-50 \mathrm{ml} / \mathrm{min} / 1.73 \mathrm{~m}^{2}$ (CKD stage 3), every 3-6 months, if eGFR is $15-29$ $\mathrm{ml} / \mathrm{min} / 1.73 \mathrm{~m}^{2}$ (CKD stage 4), and every $1-3$ months, if eGFR is $<15 \mathrm{ml} / \mathrm{min} / 1.73 \mathrm{~m}^{2}$ (CKD stage 5) [18].

\section{Practice Characteristics and Treatment Rationale}

CKD etiologies in patients presenting at the Hudson Essex Nephrology Clinic (Union City, N.J., USA) are mostly hypertensive nephrosclerosis and/or diabetic nephropathy. This urban practice represents a socioeconomically challenged and ethnically diverse demography, with a large Hispanic-American population. Adherence rates to prescribed treatments are generally high in this practice's patients.

Phosphate binders are important in CKD-MBD management to control hyperphosphatemia and secondary hyperparathyroidism (SHPT) [18]. There is some evidence that suggests that calcium-free binders are associated with lower CVD risk in CKD stages 3-5 [26]. The current KDIGO guidelines suggest restricting the dose of calcium-based binders in high-risk patients such as those with persistent hypercalcemia, adynamic bone disease, or known vascular calcifications [18]. Sevelamer carbonate, a calcium-free phosphate binder, is approved for hyperphosphatemic dialysis patients in the USA and for hyperphosphatemic patients with CKD stages 3-5 or on dialysis in many other countries.

In the author's practice, contrary to US labeling, almost all patients with CKD stages 3-5 receive sevelamer carbonate; calcium-based binders are not routinely used. Treatment with sevelamer carbonate is initiated at eGFR $<60 \mathrm{ml} / \mathrm{min} / 1.73 \mathrm{~m}^{2}$ and is typically dosed at 1 tablet daily with supper. Dose escalation of sevelamer to 2 or 3 tablets per day occurs, when there is evidence of CKD progression rather than elevated phosphate levels. The decision to use off-label dosing was based on exploratory data in predialysis CKD patients and uremic animal models that suggest sevelamer may slow the progression of CKD (particularly diabetic nephropathy) and significantly reduce serum FGF-23 [20, 27, 28]. All 4 patients described in this paper were taking 1 or more sevelamer tablets with each meal. Predialysis sevelamer use, as well as once daily dosing, is off-label in the USA: FDA-approved labeling specifies the use in hyperphosphatemic dialysis patients and administration with all meals, whereas outside the USA, sevelamer is also indicated in patients with hyperphosphatemia in 
predialysis CKD stages. Patients 3 and 4 of this paper, who presented with baseline eGFR of 20 and $24 \mathrm{ml} / \mathrm{min} / 1.73 \mathrm{~m}^{2}$, respectively, received lanthanum carbonate once daily (with 1 meal) in addition to sevelamer carbonate thrice daily (with each meal).

Angiotensin-converting enzyme inhibitors (ACEIs) and ARBs are the antihypertensive agents of choice in CKD, targeting both blood pressure $(<130 / 80 \mathrm{~mm} \mathrm{Hg}$ for CKD patients) and kidney function via inhibition of the renin-angiotensin-aldosterone system (RAAS), which reduces proteinuria and slows progression of CKD [2]. Additional classes of antihypertensive agents (e.g. doxazosin, metoprolol, hydrochlorothiazide, amlodipine, or hydralazine) are also commonly used to further ameliorate CVD risk and delay CKD progression.

Diabetes is commonly associated with CKD, and poor glycemic control contributes further to CKD progression [18]. Guidelines recommend a glycosylated hemoglobin $\left(\mathrm{HbA}_{1 \mathrm{c}}\right)$ level not exceeding 6.5-7.0\% to delay CKD progression [29]. In type 2 diabetic subjects with early CKD, all hypoglycemic agents are applicable. In advanced CKD, some drugs are contraindicated or require dose reduction because of reduced renal clearance and a resulting increased risk of hypoglycemia.

Vitamin D deficiency affects most CKD and ESRD patients. Low levels of calcidiol [25 $(\mathrm{OH})_{2}$-vitamin $\mathrm{D}_{2}$ ] are associated with a more rapid progression of CKD [2]. Current guidelines recommend supplementation with vitamin $\mathrm{D}$, once calcidiol levels drop below 30 $\mathrm{ng} / \mathrm{ml}$ using nutritional sources and/or active vitamin D analogs [5]. Active vitamin D analogs are also used to treat SHPT and high-turnover bone disease in early CKD [5]. SHPT is also treated with calcimimetics, such as cinacalcet, to increase the sensitivity of parathyroid calcium-sensing receptors.

Metabolic acidosis occurs as a result of reduced renal ammoniagenesis, leading to decreased serum bicarbonate [2]. As CKD progresses, acidosis stimulates renal ammoniagenesis and progressive tubulointerstitial injury, an effect initiated by the activation of the complement cascade [2]. Sodium bicarbonate is commonly used to restore serum bicarbonate and has been shown to significantly slow the rate of GFR decline and CKD progression [2]. A typical starting dose is $650 \mathrm{mg}$ once to thrice daily, aiming for a total blood $\mathrm{CO}_{2}$ of 19-28 mEq/l. Hyperuricemia, blood uric acid exceeding $7 \mathrm{mg} / \mathrm{dl}$, appears as GFR declines and renal uric acid excretion deteriorates; it is associated with CVD and may contribute to CKD progression. Allopurinol inhibits uric acid production and is commonly prescribed as part of the CKD treatment regimen [2]. Other drugs with uricosuric properties that are commonly used in CKD patients include fenofibrate, atorvastatin, and amlodipine.

Hyperlipidemia, most notably triglyceridemia, increases glomerular atherogenesis and contributes to CKD progression. Lipid-lowering treatment usually includes statins, omega-3 fatty acids, and fibrates to control low-density lipoprotein cholesterol (LDL-C, which should remain $<100 \mathrm{mg} / \mathrm{dl}$ ) and triglycerides (which should remain $<150 \mathrm{mg} / \mathrm{dl}$ ) [2].

Anemia affects almost all patients with CKD stages 3-5. Hypoxia and oxidative stress associated with anemia contribute to glomerulosclerosis, tubulointerstitial damage, and, ultimately, CKD progression. Anemia treatment includes erythropoiesis-stimulating agents (e.g. epoetin alfa or darbepoetin alfa), iron supplements (e.g. ferrous sulfate), and occasionally folic acid or vitamin $B_{12}$. Current guidelines recommend hemoglobin levels of 10-12 g/dl in ESRD, which can also be applied to predialysis CKD patients [2].

Additional therapeutic interventions common to this practice include multivitamins (e.g. Centrum ${ }^{\circledR}$ Silver ${ }^{\circledR}$ or Renax) to correct for mineral deficiencies related to CKD-MBD and antidepressants (e.g. venlafaxine) to combat this common comorbidity of chronic disease. Table 1 summarizes the author's main renoprotective strategies and treatment targets for each component related to CKD progression. 


\section{Case Presentations}

The 4 cases presented herein were selected retrospectively to illustrate the author's experience of successful management of severe CKD using a multifactorial treatment approach. The 4 patients described were 70-81 years old with CKD stage 3 or 4, accompanied by several comorbidities, most notably diabetes and hypertension. One patient had severe CKD stage 4 with a baseline eGFR $<20 \mathrm{ml} / \mathrm{min} / 1.73 \mathrm{~m}^{2}$. Treatment and follow-up durations were 6-7 years. Clinical characteristics and comorbidities are presented along with treatment regimens and final outcomes with respect to CKD progression (eGFR and/or serum creatinine plus other on-treatment renal chemistry parameters) in table 2 and figure 1 and figure 2. The patients provided written informed consent for the anonymous publication of their clinical data.

\section{Discussion}

In each case presented, there was evidence of slowing or prevention of CKD progression regardless of the patient's age or CKD stage. After 6 or 7 years of follow-up, eGFR was maintained at or above the levels indicative of ESRD and the need for dialysis, despite advanced CKD and comorbidities. For instance, in the case of the 70-year-old woman with CKD stage 4 and diabetes, despite a baseline eGFR $<20 \mathrm{ml} / \mathrm{min} / 1.73 \mathrm{~m}^{2}$, after 6 years of follow-up her eGFR had stabilized and was maintained $>15 \mathrm{ml} / \mathrm{min} / 1.73 \mathrm{~m}^{2}$. This preservation of remaining renal function represents a clinically meaningful delay in the requirement of renal replacement therapy. In each case, the majority of metabolic parameters related to CKD-MBD progression was within, or close to, recommended target ranges.

Hyperphosphatemia is usually associated with a rapid decline in eGFR; it also contributes to SHPT, renal osteodystrophy, and cardiovascular calcifications. Treatment of hyperphosphatemia was central to the observed benefit in these patients and was achieved using the calcium-free phosphate binders sevelamer and lanthanum carbonate either as monotherapy ( $n=2$; sevelamer) or concomitantly $(n=2)$. Both binders have demonstrated significant reductions in serum phosphorus and progression of SHPT in predialysis patients [30]. There are also reports suggesting that sevelamer may be associated with additional benefits beyond its effects on serum phosphorus and PTH. For instance, sevelamer binds dietary-derived AGEs in the intestines and reduces systemic exposure to AGEs which elicit a broad range of cellular responses leading to kidney injury. This dose-dependent effect may reduce the AGE burden and the rate of AGE-induced kidney damage in diabetic patients [28]. Sevelamer can also lower LDL-C and inflammatory markers with potentially useful antiatherogenic effects [31], and increase the clearance of uremic toxins [32]. Sevelamer reduces circulating FGF-23, which has been shown to cause left ventricular hypertrophy in animal models [19], predicts CKD progression [33] and mortality [34] in humans, and is regarded as a new target in CKD-MBD therapy. Although FGF-23 data were not collected in our representative cases, it is conceivable that FGF-23 lowering contributed to the delay in CKD progression. Furthermore, the availability of novel dosage forms with sevelamer (as powder or tablets) allows greater flexibility that may translate into increased compliance and improved phosphate control.

All of these patients had hypertension, which is independently associated with CKD progression. Potential mechanisms linking high blood pressure and kidney disease include salt retention and volume overload, increased sympathetic nervous system activity, increased RAAS activity, and increased PTH [35]. Most patients received a combination of 
RAAS inhibitors (ACEI/ARBs) and other antihypertensive classes. Reducing RAAS activity decreases proteinuria, which otherwise has direct toxic effects on the kidney and facilitates CKD progression [2]. However, ACEIs and ARBs only partially suppress the RAAS due to an up-regulation of renin activity [36]. Reduced GFR and hyperkalemia are common side effects of RAAS inhibition requiring regular monitoring. Blood pressure control without RAAS inhibition appears to be less effective in CKD patients unless there is pronounced proteinuria evident, in which case achieving a blood pressure goal does show a benefit in renal outcomes [2].

As with hypertension, hyperglycemia contributes to glomerular damage and CKD progression. Of the 2 cases with diabetes, strict glycemic control $\left(\mathrm{HbA}_{1 \mathrm{c}}<7 \%\right)$ was evident in 1 patient; at final assessment, $\mathrm{HbA}_{1 \mathrm{c}}$ was slightly elevated (7.5\%) in the other patient. Although the benefits of glycemic control in diabetic CKD with GFR $<60 \mathrm{ml} / \mathrm{min} / 1.73 \mathrm{~m}^{2}$ or macroalbuminuria have not been confirmed, glycemic control apparently benefits CKD patients with microalbuminuria [2].

Metabolic acidosis associated with low serum bicarbonate levels contributes to CKD progression and increased mortality [2]. Total $\mathrm{CO}_{2}$ levels, indicative of acidosis, were well controlled in all patients following sodium bicarbonate treatment, which has been shown to slow the rate of progression to ESRD and improve nutritional status [2]. The use of sevelamer carbonate, which has been shown to generate serum bicarbonate and improve acid-base status, may also have contributed [37].

Chronic hyperuricemia stimulates the RAAS and inhibits the release of endothelial nitric oxide, contributing to renal vasoconstriction, hypertension, and progression of renal disease [38]. Allopurinol has been shown to improve eGFR significantly over 2 years [39] and may have contributed to the delayed CKD progression observed in these cases.

Vitamin D levels were maintained $>20 \mathrm{ng} / \mathrm{ml}$ as recommended through the use of nutritional and active vitamin D analogs. In cases in which hypercalcemia developed, doses were adjusted. In addition to improving PTH, vitamin D is also associated with anti-inflammatory effects, the inhibition of mesangial and podocyte proliferation, the downregulation of RAAS by inhibiting renin production, the prevention of glomerular hypertrophy, and reduced proteinuria in different animal models of CKD [40].

Hyperlipidemia, most commonly hypertriglyceridemia, can also contribute to CKD progression by promoting atherogenesis, glomerulosclerosis, and renal fibrosis. LDL-C and triglycerides also directly stimulate mesangial cell proliferation in the glomerulus [2]. Statins were prescribed in 2 of the 4 cases to control components of dyslipidemia, and omega- 3 fatty acids to control triglycerides in 1 case. Statins have previously demonstrated a small but significant decline in annual eGFR $\left(1.22 \mathrm{ml} / \mathrm{min} / 1.73 \mathrm{~m}^{2}\right)$ and an increase in creatinine clearance compared with placebo [41]. However, uncertainty still exists whether lipidlowering medication delays CKD progression in predialysis CKD patients [2].

\section{Conclusion}

Contrary to many nephrologists' dogma, this case series highlights a subset of CKD patients who exhibited minimal disease progression according to changes in eGFR and/or serum creatinine for many years, when treated proactively with a multiple-drug regimen. These observations reinforce the value of early nephrology referral and comprehensive management of CKD and underlying hypertension and diabetes beginning at eGFR <60 $\mathrm{ml} / \mathrm{min} / 1.73 \mathrm{~m}^{2}$, and invite further research into the effects and mechanisms of CKD-MBD interventions on progression of CKD of different etiologies. 
Thomsen: Delayed Progression to Dialysis with Early and Intensive Management of Predialysis Chronic Kidney Disease: A Case-Based Approach

\section{Disclosure Statement}

Dr. Thomsen acknowledges the writing assistance of Stuart Murray, MSc, Envision Scientific Solutions, which was contracted by Sanofi for publication support services. Dr. Thomsen declares having received honoraria as a speaker from Amgen, Abbott and Sanofi. He received no compensation for the development of this paper except the provision of publication support services.

\section{References}

1 Coresh J, Selvin E, Stevens LA, Manzi J, Kusek JW, Eggers P, Van Lente F, Levey AS: Prevalence of chronic kidney disease in the United States. JAMA 2007;298:2038-2047.

-2 Turner JM, Bauer C, Abramowitz MK, Melamed ML, Hostetter TH: Treatment of chronic kidney disease. Kidney Int 2012;81:351-362.

-3 Chen SC, Hwang SJ, Tsai JC, Liu WC, Hwang SC, Chou MC, Lin MY, Chang JM, Chen HC: Early nephrology referral is associated with prolonged survival in hemodialysis patients even after exclusion of lead-time bias. Am J Med Sci 2010;339:123-126.

4 Thilly N, Boini S, Kessler M, Briancon S, Frimat L: Nephrology referral and appropriateness of therapeutic drug care in chronic kidney disease. J Nephrol 2006;19:303-311.

-5 National Kidney Foundation: K/DOQI clinical practice guidelines for chronic kidney disease: evaluation, classification, and stratification. Am J Kidney Dis 2002;39:S1-S266.

-6 Gaede P, Tarnow L, Vedel P, Parving HH, Pedersen O: Remission to normoalbuminuria during multifactorial treatment preserves kidney function in patients with type 2 diabetes and microalbuminuria. Nephrol Dial Transplant 2004;19:2784-2788.

7 Levey AS, de Jong PE, Coresh J, El Nahas M, Astor BC, Matsushita K, Gansevoort RT, Kasiske BL, Eckardt KU: The definition, classification, and prognosis of chronic kidney disease: a KDIGO Controversies Conference report. Kidney Int 2011;80:17-28.

8 Wyatt C, Konduri V, Eng J, Rohatgi R: Reporting of estimated GFR in the primary care clinic. Am J Kidney Dis 2007;49:634-641.

-9 Levey AS, Stevens LA, Schmid CH, Zhang YL, Castro AF 3rd, Feldman HI, Kusek JW, Eggers P, Van Lente F, Greene T, Coresh J: A new equation to estimate glomerular filtration rate. Ann Intern Med 2009;150:604612.

10 Mitch WE, Walser M, Buffington GA, Lemann J Jr: A simple method of estimating progression of chronic renal failure. Lancet 1976;2:1326-1328.

-11 Lorenzo V, Saracho R, Zamora J, Rufino M, Torres A: Similar renal decline in diabetic and non-diabetic patients with comparable levels of albuminuria. Nephrol Dial Transplant 2010;25:835-841.

-12 Zoppini G, Targher G, Chonchol M, Ortalda V, Negri C, Stoico V, Bonora E: Predictors of estimated GFR decline in patients with type 2 diabetes and preserved kidney function. Clin J Am Soc Nephrol 2012;7:401408.

13 Brenner BM, Cooper ME, de Zeeuw D, Keane WF, Mitch WE, Parving HH, Remuzzi G, Snapinn SM, Zhang Z, Shahinfar S: Effects of losartan on renal and cardiovascular outcomes in patients with type 2 diabetes and nephropathy. N Engl J Med 2001;345:861-869.

14 Lewis EJ, Hunsicker LG, Clarke WR, Berl T, Pohl MA, Lewis JB, Ritz E, Atkins RC, Rohde R, Raz I: Renoprotective effect of the angiotensin-receptor antagonist irbesartan in patients with nephropathy due to type 2 diabetes. N Engl J Med 2001;345:851-860.

-15 Murussi M, Gross JL, Silveiro SP: Glomerular filtration rate changes in normoalbuminuric and microalbuminuric Type 2 diabetic patients and normal individuals: A 10-year follow-up. J Diabetes Complications 2006;20:210-215.

-16 Dalrymple LS, Katz R, Kestenbaum B, Shlipak MG, Sarnak MJ, Stehman-Breen C, Seliger S, Siscovick D, Newman AB, Fried L: Chronic kidney disease and the risk of end-stage renal disease versus death. J Gen Intern Med 2011;26:379-385.

17 Tonelli M, Muntner P, Lloyd A, Manns BJ, Klarenbach S, Pannu N, James MT, Hemmelgarn BR: Risk of coronary events in people with chronic kidney disease compared with those with diabetes: a populationlevel cohort study. Lancet 2012;380:807-814.

18 Kidney Disease Improving Global Outcomes (KDIGO) CKD-MBD Work Group: KDIGO clinical practice guideline for the diagnosis, evaluation, prevention, and treatment of chronic kidney disease-mineral and bone disorder (CKD-MBD). Kidney Int 2009;76:S1-S130. 
Thomsen: Delayed Progression to Dialysis with Early and Intensive Management of Predialysis Chronic Kidney Disease: A Case-Based Approach

19 Faul C, Amaral AP, Oskouei B, Hu MC, Sloan A, Isakova T, Gutiérrez OM, Aguillon-Prada R, Lincoln J, Hare JM, Mundel P, Morales A, Scialla J, Fischer M, Soliman EZ, Chen J, Go AS, Rosas SE, Nessel L, Townsend RR, Feldman HI, St John Sutton M, Ojo A, Gadegbeku C, Di Marco GS, Reuter S, Kentrup D, Tiemann K, Brand M, Hill JA, Moe OW, Kuro OM, Kusek JW, Keane MG, Wolf M: FGF23 induces left ventricular hypertrophy. J Clin Invest 2011;121:4393-4408.

-20 Oliveira RB, Cancela AL, Graciolli FG, Dos Reis LM, Draibe SA, Cuppari L, Carvalho AB, Jorgetti V, Canziani ME, Moyses RM: Early control of PTH and FGF23 in normophosphatemic CKD patients: a new target in CKDMBD therapy? Clin J Am Soc Nephrol 2010;5:286-291.

-21 Yilmaz MI, Sonmez A, Saglam M, Yaman H, Kilic S, Eyileten T, Caglar K, Oguz Y, Vural A, Yenicesu M, Mallamaci F, Zoccali C: Comparison of calcium acetate and sevelamer on vascular function and fibroblast growth factor 23 in CKD patients: a randomized clinical trial. Am J Kidney Dis 2012;59:177-185.

-22 Kahonen M, Nappi S, Jolma P, Hutri-Kahonen N, Tolvanen JP, Saha H, Koivisto P, Krogerus L, Kalliovalkama J, Porsti I: Vascular influences of calcium supplementation and vitamin D-induced hypercalcemia in NaClhypertensive rats. J Cardiovasc Pharmacol 2003;42:319-328.

23 Phan O, Ivanovski O, Nikolov IG, Joki N, Maizel J, Louvet L, Chasseraud M, Nguyen-Khoa T, Lacour B, Drueke TB, Massy ZA: Effect of oral calcium carbonate on aortic calcification in apolipoprotein E-deficient (apoE-/-) mice with chronic renal failure. Nephrol Dial Transplant 2008;23:82-90.

24 Hill KM, Martin BR, Wastney ME, McCabe GP, Moe SM, Weaver CM, Peacock M: Oral calcium carbonate affects calcium but not phosphorus balance in stage 3-4 chronic kidney disease. Kidney Int 2012.

Reid IR, Bolland MJ: Calcium supplements: bad for the heart? Heart 2012;98:895-896. Russo D, Miranda I, Ruocco C, Battaglia Y, Buonanno E, Manzi S, Russo L, Scafarto A, Andreucci VE: The progression of coronary artery calcification in predialysis patients on calcium carbonate or sevelamer. Kidney Int 2007;72:1255-1261.

27 Nagano N, Miyata S, Obana S, Kobayashi N, Fukushima N, Burke SK, Wada M: Sevelamer hydrochloride, a phosphate binder, protects against deterioration of renal function in rats with progressive chronic renal insufficiency. Nephrol Dial Transplant 2003;18:2014-2023.

28 Vlassara H, Uribarri J, Cai W, Goodman S, Pyzik R, Post J, Grosjean F, Woodward M, Striker GE: Effects of sevelamer on HbA1c, inflammation, and advanced glycation end products in diabetic kidney disease. Clin J Am Soc Nephrol 2012;7:934-942.

29 KDOQI: KDOQI Clinical practice guidelines and clinical practice recommendations for diabetes and chronic kidney disease. Am J Kidney Dis 2007;49:S12-S154.

-30 Block GA, Wheeler DC, Persky MS, Kestenbaum B, Ketteler M, Spiegel DM, Allison MA, Asplin J, Smits G, Hoofnagle AN, Kooienga L, Thadhani R, Mannstadt M, Wolf M, Chertow GM: Effects of phosphate binders in moderate CKD. J Am Soc Nephrol 2012;23:1407-1415.

-31 Ferramosca E, Burke S, Chasan-Taber S, Ratti C, Chertow GM, Raggi P: Potential antiatherogenic and antiinflammatory properties of sevelamer in maintenance hemodialysis patients. Am Heart J 2005;149:820825 .

- 32 Nikolov IG, Joki N, Maizel J, Lacour B, Drueke TB, Massy ZA: Pleiotropic effects of the non-calcium phosphate binder sevelamer. Kidney Int Suppl 2006:S16-S23.

33 Kendrick J, Cheung AK, Kaufman JS, Greene T, Roberts WL, Smits G, Chonchol M: FGF-23 associates with death, cardiovascular events, and initiation of chronic dialysis. J Am Soc Nephrol 2011;22:1913-1922.

-34 Isakova T, Xie H, Yang W, Xie D, Anderson AH, Scialla J, Wahl P, Gutiérrez OM, Steigerwalt S, He J, Schwartz S, Lo J, Ojo A, Sondheimer J, Hsu CY, Lash J, Leonard M, Kusek JW, Feldman HI, Wolf M: Fibroblast growth factor 23 and risks of mortality and end-stage renal disease in patients with chronic kidney disease. JAMA 2011;305:2432-2439.

35 Ravera M, Re M, Deferrari L, Vettoretti S, Deferrari G: Importance of blood pressure control in chronic kidney disease. J Am Soc Nephrol 2006;17:S98-S103.

- 36 Rastogi A, Rashid M, Wright RF: Reducing cardiorenal risk through combination therapy with a direct renin inhibitor. J Clin Hypertens (Greenwich) 2011;13:848-855.

-37 Gonzalez E, Schomberg J, Amin N, Salusky IB, Zaritsky J: Sevelamer carbonate increases serum bicarbonate in pediatric dialysis patients. Pediatr Nephrol 2010;25:373-375.

-38 Johnson RJ, Kang DH, Feig D, Kivlighn S, Kanellis J, Watanabe S, Tuttle KR, Rodriguez-Iturbe B, HerreraAcosta J, Mazzali M: Is there a pathogenetic role for uric acid in hypertension and cardiovascular and renal disease? Hypertension 2003;41:1183-1190.

-39 Goicoechea M, de Vinuesa SG, Verdalles U, Ruiz-Caro C, Ampuero J, Rincon A, Arroyo D, Luno J: Effect of allopurinol in chronic kidney disease progression and cardiovascular risk. Clin J Am Soc Nephrol 2010;5:1388-1393.

40 Tian J, Liu Y, Williams LA, de Zeeuw D: Potential role of active vitamin D in retarding the progression of chronic kidney disease. Nephrol Dial Transplant 2007;22:321-328.

-41 Sandhu S, Wiebe N, Fried LF, Tonelli M: Statins for improving renal outcomes: a meta-analysis. J Am Soc Nephrol 2006;17:2006-2016. 
Thomsen: Delayed Progression to Dialysis with Early and Intensive Management of Predialysis Chronic Kidney Disease: A Case-Based Approach

Table 1. Renoprotective strategies for slowing CKD progression

\begin{tabular}{|c|c|c|}
\hline Parameter & Goal & Intervention \\
\hline eGFR & $\begin{array}{l}\text { KDIGO classification: } \\
\text { stage 1: eGFR } \geq 90 \mathrm{ml} / \mathrm{min} / 1.73 \mathrm{~m}^{2} \\
\text { stage 2: eGFR } 60-89 \mathrm{ml} / \mathrm{min} / 1.73 \mathrm{~m}^{2} \\
\text { stage 3: eGFR } 30-59 \mathrm{ml} / \mathrm{min} / 1.73 \mathrm{~m}^{2} \\
\text { stage 4: eGFR } 15-29 \mathrm{ml} / \mathrm{min} / 1.73 \mathrm{~m}^{2} \\
\text { stage } 5: \text { eGFR }<15 \mathrm{ml} / \mathrm{min} / 1.73 \mathrm{~m}^{2}\end{array}$ & Phosphate binders, RAAS inhibitors (ACEIs/ARBs) \\
\hline Blood pressure control & $\begin{array}{l}<130 / 80 \mathrm{~mm} \mathrm{Hg} \text {, if proteinuria }<1 \mathrm{~g} / \text { day } \\
<125 / 75 \mathrm{~mm} \mathrm{Hg} \text {, if proteinuria }>1 \mathrm{~g} / \text { day }\end{array}$ & ACEIs/ARBs, sodium restriction, diuretics \\
\hline Reduction in proteinuria & $<0.5 \mathrm{~g} /$ day & ACEIs/ARBs \\
\hline Glycemic control & $\mathrm{HbA}_{1 \mathrm{c}}<7 \%$ & $\begin{array}{l}\text { Dietary counseling, oral hypoglycemic agents, } \\
\text { insulin }\end{array}$ \\
\hline Dietary protein restriction & $0.6-0.8 \mathrm{~g} / \mathrm{kg} /$ day & Dietary counseling \\
\hline Lipid lowering & $\begin{array}{l}\mathrm{LDL}<100 \mathrm{mg} / \mathrm{dl} \\
\text { Triglycerides }<150 \mathrm{mg} / \mathrm{dl}\end{array}$ & $\begin{array}{l}\text { Dietary counseling, statins, omega- } 3 \text { fatty acids, } \\
\text { fibrates }\end{array}$ \\
\hline Lifestyle modifications & $\begin{array}{l}\text { Smoking cessation, achieving ideal body } \\
\text { weight, regular exercise }\end{array}$ & Counseling, exercise program \\
\hline PTH control & $\begin{array}{l}\text { KDIGO goalsa: } \\
\text { stage 3: } 35-70 \mathrm{pg} / \mathrm{ml} \\
\text { stage 4: } 70-110 \mathrm{pg} / \mathrm{ml} \\
\text { stage } 5: 150-300 \mathrm{pg} / \mathrm{ml}\end{array}$ & $\begin{array}{l}\text { Active vitamin D, calcimimetics (e.g. cinacalcet), } \\
\text { phosphate binders }\end{array}$ \\
\hline Phosphorus control & $\begin{array}{l}\text { Target range: } \\
\text { stages } 3 \text { and } 4: 2.7-4.6 \mathrm{mg} / \mathrm{dl} \\
\text { stage } 5 \text { or ESRD: } 3.5-5.5 \mathrm{mg} / \mathrm{dl}\end{array}$ & Phosphate binders \\
\hline Hypercalcemia control & $\begin{array}{l}8.5-10.2 \mathrm{mg} / \mathrm{dl} \\
\text { calcium-phosphorus product }<55 \mathrm{mg}^{2} / \mathrm{dl}^{2}\end{array}$ & $\begin{array}{l}\text { Non-calcium phosphate binders, dietary } \\
\text { counseling, calcimimetics }\end{array}$ \\
\hline Anemia control & Target hemoglobin $11-12 \mathrm{~g} / \mathrm{dl}$ & Erythropoiesis-stimulating agents, ferrous sulfate \\
\hline Hyperuricemia control & Serum uric acid $<7 \mathrm{mg} / \mathrm{dl}$ & Allopurinol \\
\hline Vitamin D & Serum $25(\mathrm{OH}) \mathrm{D}_{2} \geq 20 \mathrm{ng} / \mathrm{ml}$ & Nutritional and active vitamin D \\
\hline Metabolic acidosis & Bicarbonate (or total $\mathrm{CO}_{2}$ ) 19-28 mEq/l & Sodium bicarbonate \\
\hline
\end{tabular}

a In the author's practice, PTH management is individualized, and PTH goals are dependent on PTH history. For instance, a patient who has PTH $70 \mathrm{pg} / \mathrm{ml}$ in CKD stage 3 is managed to remain at $70 \mathrm{pg} / \mathrm{ml}$ in subsequent stages 4 and 5 if possible; a patient who starts treatment with $300 \mathrm{pg} / \mathrm{ml}$ is managed to keep within $150-300 \mathrm{pg} / \mathrm{ml}$. 
Thomsen: Delayed Progression to Dialysis with Early and Intensive Management of

Predialysis Chronic Kidney Disease: A Case-Based Approach

Table 2. Summary of the clinical characteristics, treatment regimen and CKD outcome

\begin{tabular}{ll}
\hline Case & $\begin{array}{l}\text { Clinical characteristics and } \\
\text { comorbidities }\end{array}$ \\
\hline $1 \quad \begin{array}{l}\text { 78-year-old } \\
\text { woman with } \\
\text { moderate } \\
\text { CKD stage } 3\end{array}$ & $\begin{array}{l}\text { Hypertensive arteriolar } \\
\text { nephrosclerosis and 7-year } \\
\text { history of psoriasis; adrenal } \\
\text { adenoma; anemia; homocys- } \\
\text { tinemia; hyperlipidemia; } \\
\text { hypertension; hyperurice- } \\
\text { mia; iron deficiency; macular } \\
\text { degeneration; rheumatoid } \\
\text { arthritis; SHPT; vitamin D } \\
\text { deficiency }\end{array}$
\end{tabular}

Treatment regimen ${ }^{\mathrm{a}}$

Treatment consisted of aldactazide $25 \mathrm{mg}$; allopurinol $100 \mathrm{mg}$; aspirin $81 \mathrm{mg}$; cardizem CD $120 \mathrm{mg}$; rosuvastatin $5 \mathrm{mg}$; Feosol 45 mg; Folbee Plus 5/1.5/25 mg; methotrexate $2.5 \mathrm{mg}$ ( 3 tablets once a week), and etanercept $50 \mathrm{mg} / \mathrm{ml}$ (once a week) to treat psoriasis and rheumatoid arthritis; Ocuvite (eye vitamins); sevelamer $800 \mathrm{mg}$ (thrice a day with meals); cinacalcet $30 \mathrm{mg}$, and paricalcitol $1 \mu \mathrm{g}$

Outcome at final assessment

After 7 years of therapy, serum creatinine declined from $1.5 \mathrm{mg} / \mathrm{dl}$ and remained stable at approx. $1.3 \mathrm{mg} / \mathrm{dl}$ and the MDRD creatinine clearance increased from 37 to $42 \mathrm{ml} / \mathrm{min}$. This was accompanied by stabilized eGFR $>35 \mathrm{ml} / \mathrm{min} / 1.73 \mathrm{~m}^{2}$ and, despite a sharp decline after 5 years, was maintained $>40 \mathrm{ml} / \mathrm{min} / 1.73 \mathrm{~m}^{2}$ at the final assessment.

KDIGO-recommended targets were achieved for key parameters (initial and final values): serum calcium (10.5 and $10.1 \mathrm{mg} / \mathrm{dl}$ ); phosphorus ( 3.4 and 3.2 $\mathrm{mg} / \mathrm{dl}$ ); PTH (95 and $75 \mathrm{pg} / \mathrm{ml}$ ); vitamin D (10.7 and $26.5 \mathrm{ng} / \mathrm{ml})$.

Other parameters at goal included total $\mathrm{CO}_{2}(29 \mathrm{mEq} / \mathrm{l})$ and uric acid, which was reduced from an initial value of 7.4 to 5.4 $\mathrm{mg} / \mathrm{dl}$.

2 78-year-old Hypertension; type 2 diabetic man diabetes; atrial fibrillation; with moder- benign prostatic hyperate CKD trophy; homocystinemia; stage 3 hyperlipidemia; hyperuricemia; SHPT; vitamin D deficiency; Alzheimer's disease; metabolic acidosis; MBD
Pioglitazone $15 \mathrm{mg}$ (1/2 tablet daily) for glycemic control; allopurinol $100 \mathrm{mg}$ (twice daily); amlodipine $5 \mathrm{mg}$; ezetimibe $10 \mathrm{mg}$; rosuvastatin $10 \mathrm{mg}$, and carvedilol $12.5 \mathrm{mg}$ (twice daily); multivitamins (Cerefolin 6/5/50/1 mg and Diatx Zn 5/1.5/25 mg; warfarin $5 \mathrm{mg}$; ergocalciferol (vitamin $\mathrm{D}_{2}$ ) 50,000 units (once every other week), and paricalcitol $1 \mu \mathrm{g}$ (once every other day); rivastigmine transdermal $4.6 \mathrm{mg}$ (as directed) for Alzheimer's disease, and memantine $5 \mathrm{mg}$ to treat dementia associated with Alzheimer's disease; sertraline $50 \mathrm{mg}$ (antidepressant); finasteride $5 \mathrm{mg}$, and alfuzosin $10 \mathrm{mg}$ for benign prostatic hyperplasia; sevelamer $800 \mathrm{mg}$ (thrice a day with meals)

\section{70-year-old Hypertension; type 2} hypertensive diabetes; hyperlipidemia; diabetic woman with severe CKD stage 4 ment; metabolic acidosis; hyperuricemia; iron deficiency; knee replaceMBD; osteoarthritis; vitamin D deficiency

\section{Allopurinol $300 \mathrm{mg}$; glimepiride $4 \mathrm{mg}$;} insulin glulisine $100 \mathrm{U} / \mathrm{ml}$ (8 units in the morning and 8 units at night), and insulin glargine $100 \mathrm{U} / \mathrm{ml}$ (8-10 units daily); diltiazem $180 \mathrm{mg}$ ( 2 capsules daily); valsartan/hydrochlorothiazide 160/12.5 $\mathrm{mg}$ (twice daily); furosemide $80 \mathrm{mg}$ (1 tablet every other morning), and atorvastatin $80 \mathrm{mg}$; multivitamins (Centrum Silver and Folbee Plus 5/1.5/25 mg, vitamin C $600 \mathrm{mg}$, vitamin E); Pro-Stat 64 ( $30 \mathrm{ml}$ twice daily) liquid protein formula; ergocalciferol (vitamin $D_{2}$ ) 50,000 units (one every other week); raloxifene $60 \mathrm{mg}$ (for her osteoporosis); ferrous sulfate 325 mg (twice daily on empty stomach); lanthanum carbonate $1,000 \mathrm{mg}$ (twice daily with meals), and sevelamer $800 \mathrm{mg}$ (thrice daily with meals); sodium bicarbonate $650 \mathrm{mg}$ (twice daily)
After 7 years, serum creatinine declined from 1.9 to $1.46 \mathrm{mg} / \mathrm{dl}$ and GFR was stabilized at $>40 \mathrm{ml} / \mathrm{min} / 1.73 \mathrm{~m}^{2}$ (maintained at stage 3). Important parameters (with initial and final values) were maintained within range: serum calcium ( 9.6 and $9.3 \mathrm{mg} / \mathrm{dl})$; serum phosphorus (2.8 and $3.1 \mathrm{mg} / \mathrm{dl}$ ); intact PTH (50.4 and $47 \mathrm{pg} / \mathrm{ml}$ ); $\mathrm{HbA}_{1 \mathrm{c}}$ (5.9\% and $6.1 \%$ ).

Other parameters at goal included triglycerides ( $86 \mathrm{mg} / \mathrm{dl})$; total $\mathrm{CO}_{2}(21$ $\mathrm{mEq} / \mathrm{l})$; hemoglobin $(12.2 \mathrm{~g} / \mathrm{dl})$, and uric acid (reduced from 7.7 to $4.3 \mathrm{mg} / \mathrm{dl}$ ).

After 6 years of follow-up, eGFR remained stable $\left(20 \mathrm{ml} / \mathrm{min} / 1.73 \mathrm{~m}^{2}\right.$ at presentation and $17 \mathrm{ml} / \mathrm{min} / 1.73 \mathrm{~m}^{2}$ at final assessment).

Despite a peak in serum creatinine to almost $4 \mathrm{mg} / \mathrm{dl}$, the final level after 6 years was similar to the baseline level $(2.5$ $\mathrm{mg} / \mathrm{dl}$ ).

Initial and final values for serum phosphorus ( 4.7 and $3.6 \mathrm{mg} / \mathrm{dl}$ ); calcium ( 8.9 and $9.5 \mathrm{mg} / \mathrm{dl}) ;$ iPTH (76.6 and $36.7 \mathrm{pg} / \mathrm{ml}$ ) were all within range.

Other parameters at goal included total $\mathrm{CO}_{2}(24 \mathrm{mEq} / \mathrm{l})$ and uric acid $(3.1 \mathrm{mg} / \mathrm{dl})$. $\mathrm{HbA}_{1 \mathrm{c}}(7.5 \%)$ levels were slightly elevated above the recommended target at final assessment. 
Thomsen: Delayed Progression to Dialysis with Early and Intensive Management of Predialysis Chronic Kidney Disease: A Case-Based Approach

4 81-year-old Hypertension; anemia, hypertensive benign prostatic hyperman with plasia; hyperlipidemia; CKD stage 4 hyperuricemia; metabolic acidosis; MBD; SHPT; vitamin D deficiency
Multivitamins and natural health products including Folbee Plus 5/1.5/25 mg, benefiber (guar gum) $1 \mathrm{~g}$ ( 3 tablets twice a day), Centrum Silver, fish oil omega 3-6-9 capsule Delayed Release 300-1,000 mg (twice daily), Ginkgo Biloba $40 \mathrm{mg}$ (an antioxidant to treat dementia), niacinamide $250 \mathrm{mg}$ (thrice daily) and Joint Support (glucosamine, etc.) 375/300/50/2 mg (3 capsules twice a day). Medications included allopurinol $300 \mathrm{mg}$; darbepoetin alfa (60-100 units every 2 weeks, if hemoglobin levels warranted); atenolol $25 \mathrm{mg}$. aspirin $325 \mathrm{mg}$; valsartan $80 \mathrm{mg}$, and furosemide $80 \mathrm{mg}$ (every other day); ergocalciferol (vitamin $D_{2}$ ) 50,000 units (one capsule a week), and doxercalciferol $0.5 \mu \mathrm{g}$ (every other day); lanthanum carbonate $1,000 \mathrm{mg}$ (once daily with supper), and sevelamer $800 \mathrm{mg}$ ( 2 tablets thrice a day with meals); polyethylene glycol $17 \mathrm{~g}$ (1 capsule with water once to twice daily) to alleviate constipation; sodium bicarbonate $650 \mathrm{mg}$ ( 2 tablets four times daily); terazosin $5 \mathrm{mg}$ (for benign prostatic hyperplasia)

a All doses are once daily unless indicated otherwise; in some cases, multivitamins (e.g. Centrum Silver) and vitamins such as vitamin $\mathrm{E}$ were over-the-counter and used on the patients' own initiative, and as such doses are not provided. 

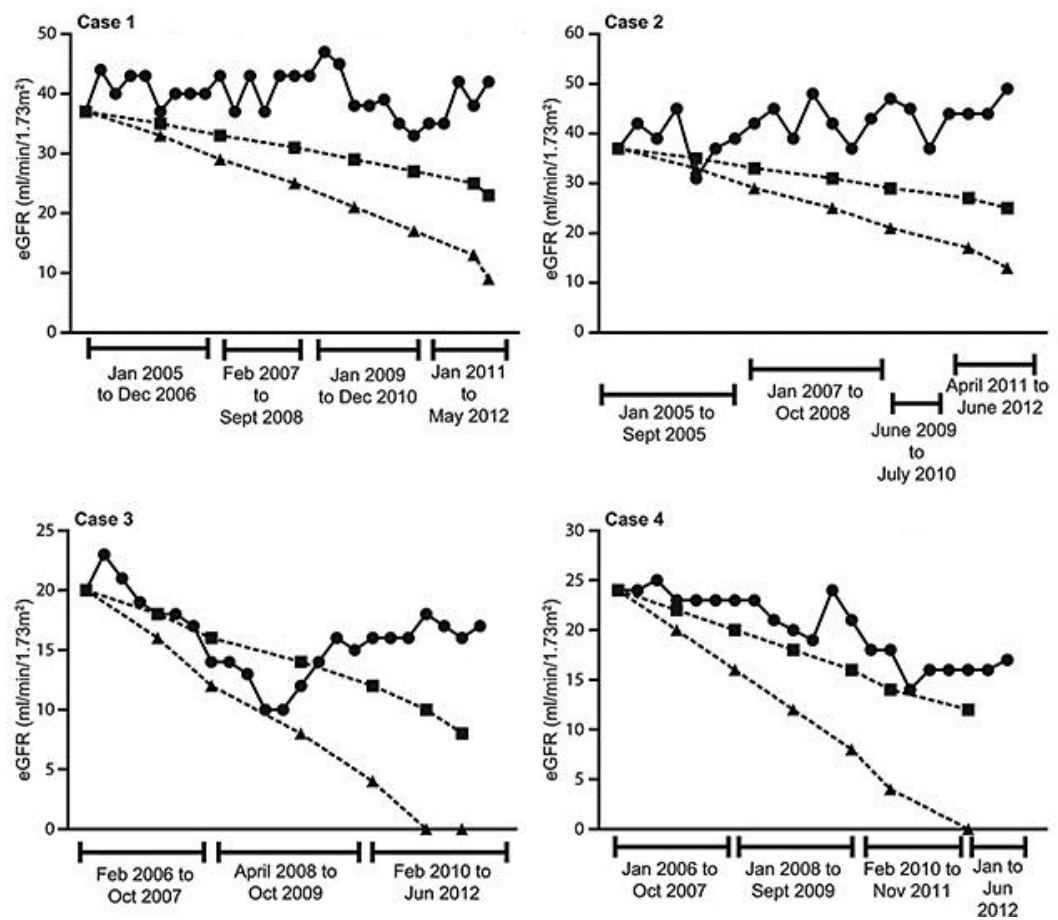

Fig. 1. Temporal changes in eGFR after treatment ( $)$ and the expected decline in eGFR based on annual decreases of $2(\boldsymbol{\nabla})$ and $4 \mathrm{ml} / \mathrm{min} / 1.73 \mathrm{~m}^{2}(\mathbf{\Delta})$. Case 1: 78-year-old woman with moderate CKD stage 3; Case 2: 78-year-old diabetic man with moderate CKD stage 3; Case 3: 70-year-old hypertensive diabetic woman with severe CKD stage 4; Case 4: 81-year-old hypertensive man with CKD stage 4. 

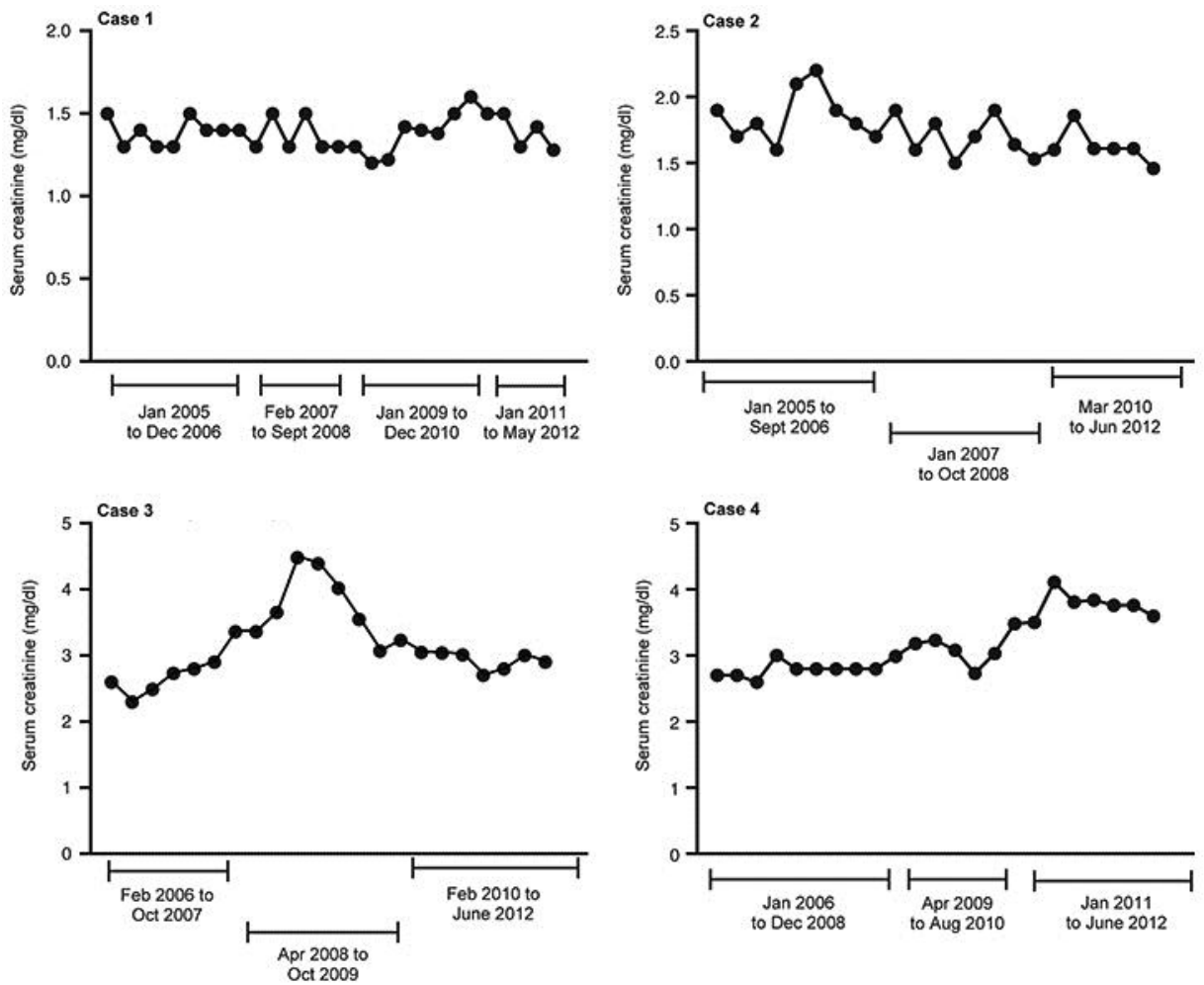

Fig. 2. Temporal changes in serum creatinine. Case 1: 78-year-old woman with moderate CKD stage 3; Case 2: 78-year-old diabetic man with moderate CKD stage 3; Case 3: 70-year-old hypertensive diabetic woman with severe CKD stage 4; Case 4: 81-year-old hypertensive man with CKD stage 4. 